\title{
Unusual Synergism of Transferrin and Citrate in the Regulation of Ti(IV) Speciation, Transport, and Toxicity
}

Arthur D. Tinoco, ${ }^{*, *, \#}$ Manoj Saxena, ${ }^{\ddagger}, \#$ Shweta Sharma, ${ }^{\ddagger}$ Nicholas Noinaj, ${ }^{\S}$ Yamixa Delgado, ${ }^{\dagger}$ Ernesto P. Quiñones González, ${ }^{\dagger}$ Steven E. Conklin, ${ }^{\dagger}$ Nicole Zambrana, ${ }^{\dagger}$ Sergio A. Loza-Rosas, ${ }^{\dagger}$ and Timothy B. Parks"

${ }^{\dagger}$ Department of Chemistry and ${ }^{\ddagger}$ Department of Environmental Sciences, University of Puerto Rico, Río Piedras Campus, Río Piedras, Puerto Rico 00931

${ }^{\S}$ Department of Biological Sciences, Purdue University, 240 S. Martin Jischke Drive, Hockmeyer Hall, West Lafayette, Indiana 47907, United States

"VA Caribbean Healthcare System, 10 Casia Street, San Juan, Puerto Rico 00921

Supporting Information

ABSTRACT: Human serum transferrin (sTf) is a protein that mediates the transport of iron from blood to cells. Assisted by the synergistic anion carbonate, sTf transports Fe(III) by binding the metal ion in a closed conformation. Previous studies suggest sTfs role as a potential transporter of other metals such as titanium. Ti is a widely used metal in colorants, foods, and implants. A substantial amount of $\mathrm{Ti}$ is leached into blood from these implants. However, the fate of the leached $\mathrm{Ti}$ and its transport into the cells is not known. Understanding $\mathrm{Ti}$

Ti(IV)-Bound Serum Transferrin

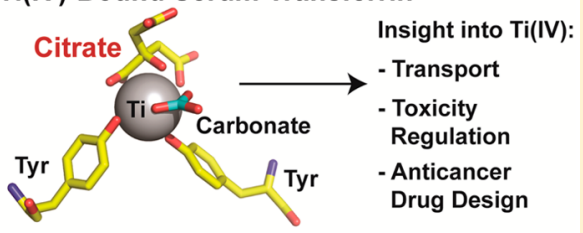
interaction with sTf assumes a greater significance with our ever increasing exposure to $\mathrm{Ti}$ in the form of implants. On the basis of in vitro studies, it was speculated that transferrin can bind $\mathrm{Ti}(\mathrm{IV})$ assisted by a synergistic anion. However, the role and identity of the synergistic anion(s) and the conformational state in which sTf binds $\mathrm{Ti}(\mathrm{IV})$ are not known. Here we have solved the first X-ray crystal structure of a Ti(IV)-bound sTf. We find that sTf binds Ti(IV) in an open conformation with both carbonate and citrate as synergistic anions at the metal binding sites, an unprecedented role for citrate. Studies with cell lines suggest that Ti(IV)-sTf is transported into cells and that sTf and citrate regulate the metal's blood speciation and attenuate its cytotoxic property. Our results provide the first glimpse into the citrate-transferrin synergism in the regulation of $\mathrm{Ti}(\mathrm{IV})$ bioactivity and offers insight into the future design of $\mathrm{Ti}(\mathrm{IV})$-based anticancer drugs.

\section{INTRODUCTION}

Titanium is a ubiquitous metal that predominantly exists as $\mathrm{Ti}(\mathrm{IV})$ in our oxidizing environment. As Ti(IV), it is highly susceptible to hydrolysis and exists at very low concentrations (femtomolar) in water due to precipitation as titanium dioxide $\left(\mathrm{TiO}_{2}\right)$, a white solid. ${ }^{1} \mathrm{TiO}_{2}$ is the major form of $\mathrm{Ti}(\mathrm{IV})$, commonly used as the pigment of white paint. Ti(IV) can easily enter into the human body via foods and liquids or as $\mathrm{TiO}_{2}$ particles in toothpastes or the paint dust that we breathe. These dust particles are the reason that $\mathrm{Ti}$ is found at its highest levels in the lungs. ${ }^{2}$ There is no known natural function for $\mathrm{Ti}$ in people. Nonetheless, it displays excellent potential for multiple uses in the medical field. Following initial promise of two $\mathrm{Ti}(\mathrm{IV})$ compounds (titanocene dichloride and budotitane) as anticancer agents, several $\mathrm{Ti}(\mathrm{IV})$ compounds are in development for this application to overcome the limitations of the platinum(II) drugs, ${ }^{3}$ which are one of the major drugs in the market but suffer from a narrow spectrum of effect, many side effects, and a rapidly acquired resistance by cancer cells.

$\mathrm{Ti}$ has been extremely valuable in its use in prosthetics. ${ }^{4-6}$ Ti's property of osseointegration, the ability to integrate and be structurally accepted by bone without the requirement of soft tissue connection, demonstrates that it can play structure and templating roles in biology. ${ }^{4}$ This property in addition to its general biocompatibility, high corrosion resistance, low specific gravity, and weak magnetism are the reasons why $\mathrm{Ti}$ has been widely applied in the development of prosthetics. ${ }^{5}$ On average, hundreds of thousands of prosthetics are implanted in people every year. ${ }^{4}$ With increasing life expectancy our dependence on Ti for prosthetic use is bound to increase. Current evidence suggests that the body's interaction with Ti-containing implants extends beyond a simple passive, biocompatible one. The Ti reacts with biological fluids and leaches into the circulatory system leading to Ti(IV) levels in the blood elevating to high nanomolar levels, ${ }^{7}$ nearly 50 times greater than people with no implants. The leached, soluble $\mathrm{Ti}(\mathrm{IV})$ is found to be almost $100 \%$ serum transferrin (sTf) bound. ${ }^{7}$ The long-term effect of this pool of $\mathrm{Ti}(\mathrm{IV})$-bound sTf is not clear.

A textbook presentation of sTf highlights its function as a primary agent that binds circulating plasma iron in a bioavailable $\mathrm{Fe}$ (III) form for delivery into mammalian cells. It is typically $30 \% \mathrm{Fe}$ (III) saturated. ${ }^{8}$ A lesser studied property of sTf is its function as a noniron metal transporter. This function

Received: February 22, 2016

Published: April 12, 2016 
has been proposed to occur in targeted efforts to deliver certain metals as therapeutics (chromium, bismuth, gallium, indium, ruthenium, titanium, vanadium) and during environmental increases in metals resulting in cellular toxicity (aluminum, lanthanides, and actinides). ${ }^{9,10}$ There is some evidence for endogenous transport of manganese(III) by sTf., $^{9,11}$ The coordination of sTf to all metals is generally thought to be identical. STf is a bilobal, $80 \mathrm{kDa}$ glycoprotein with its $\mathrm{N}$ - and C-lobes divided into two subdomains (N1 and N2, and $\mathrm{C} 1$ and $\mathrm{C} 2$ ) that form two $\mathrm{Fe}$ (III) binding sites. $\mathrm{Fe}$ (III) is coordinated by an aspartic acid from the N1- or C1-subdomain, a tyrosine in the hinge near the $\mathrm{N} 2$ - or $\mathrm{C} 2$-subdomain, another tyrosine in the N2- or C2-subdomain, and a histidine in the hinge near the N1- or C1-subdomain (Figure 1A). The coordination is

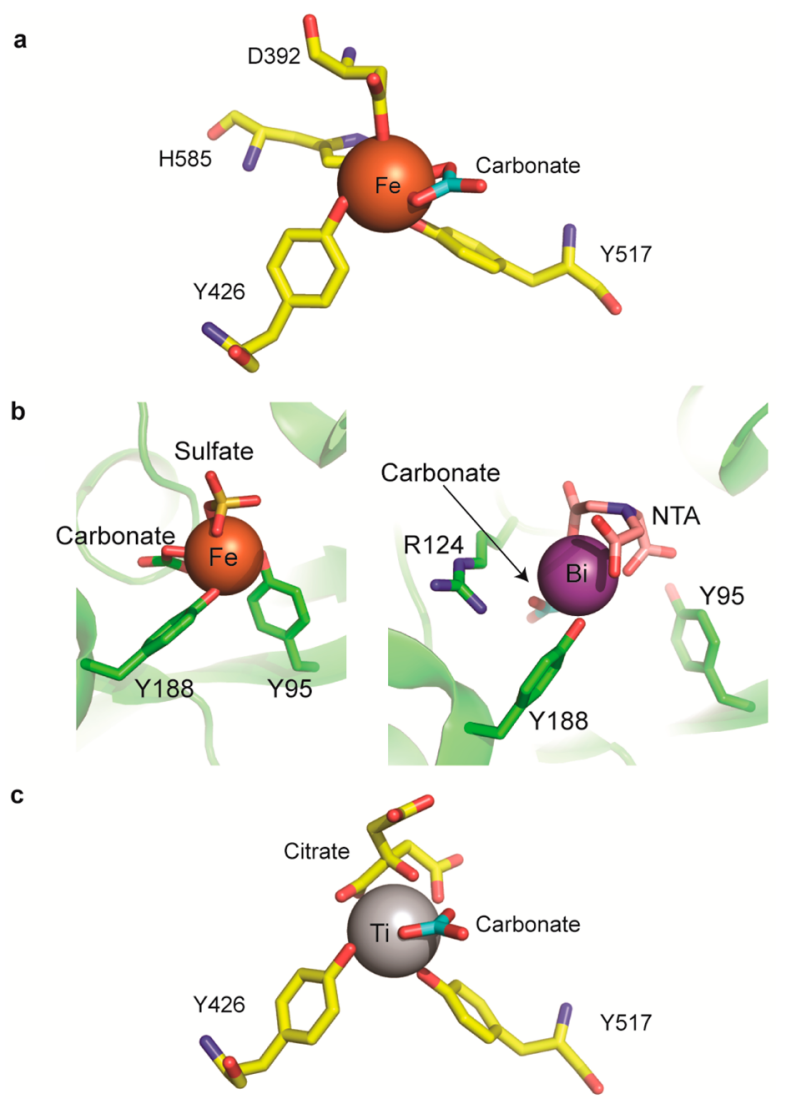

Figure 1. Metal coordinating ligands in $\mathrm{Fe}(\mathrm{III})$-bound and $\mathrm{Ti}(\mathrm{IV})$ serotransferrin crystal structures. (a) Metal binding site in the C-lobe of serotransferrin (3QYT) showing the iron binding residues (yellow) and the synergistic anion carbonate (blue). (b) N-Site structures showing other anions $\left(\mathrm{SO}_{4}{ }^{2-}\right.$ and $\left.\mathrm{NTA}^{3-}\right)$ maintaining metal-bound sTf in a semiopen conformation (3QYT and 4HOW). (c) The C-site of Ti-bound serotransferrin. In contrast to $\mathrm{A}$, in Ti-sTf in place of the His-585 and Asp-392 a bidentate synergistic citrate anion provides the necessary contacts to fulfill the coordination of $\mathrm{Ti}(\mathrm{IV})$. The $\mathrm{Ti}(\mathrm{IV})$ is in an open conformation.

completed by the synergistic anion carbonate, which coordinates in a bidentate form, or a carbonate-like molecule with certain size limitations. ${ }^{12}$ The carbonate is stably bound to an arginine residue (Arg124 and Arg456, at the N- and C-site, respectively) and is a requirement for the specific binding of $\mathrm{Fe}(\mathrm{III})$ to sTf. $^{13} \mathrm{Fe}$ (III) binding changes the protein's lobes from an open to a closed conformation, ${ }^{14}$ significantly stabilizing the protein. ${ }^{15}$ Although the coordination of all metal ions is presumed to be identical to that of $\mathrm{Fe}(\mathrm{III})$, it is reasoned that the difference in metal ion affinity to sTf stems from a difference in the Lewis acidity of the ions, with stronger Lewis acidic metals having a higher affinity to the Lewis basic residues of the binding site. ${ }^{16}$ Vanadium, which is extremely hydrolysis prone, is known to differ in its coordination to sTf by providing its own synergistic anion in the form of an oxo moiety in place of carbonate. ${ }^{17}$

A recent crystallographic study challenges the consensus on sTf metal binding by presenting metal ions bound in a semiopen conformation. ${ }^{18}$ These conformations were achieved with the anions sulfate and nitrilotriacetate (NTA), binding the metal ions $\mathrm{Fe}(\mathrm{III})$ and $\mathrm{Bi}(\mathrm{III})$, respectively, at positions in the $\mathrm{N}$-site that prevented the coordination of two or three of the protein residues and thus restricted lobe closure (Figure 1B). In these structures, carbonate was bound to the metal ions at its typical Arg binding site. These structures were likely the product of crystallization conditions and may not reflect biological relevance.

How noncarbonate, physiological anions work in synergism with sTf to transport noniron metals is an unexplored area. This is an extremely important question especially as it relates to the biological fate of $\mathrm{Ti}(\mathrm{IV})$-bound sTf formed from $\mathrm{Ti}$ implant leaching. Small molecules must be involved in both the chelation of $\mathrm{Ti}(\mathrm{IV})$ during or following the leaching process or else the metal would completely precipitate, and in the delivery of the metal ion to sTf. The bioactive anion citrate is believed to contribute to the solubilization and binding of Ti released from implants. ${ }^{19,20}$ As of yet, no association has been made between citrate chelation of $\mathrm{Ti}(\mathrm{IV})$ and $\mathrm{Ti}(\mathrm{IV})$ delivery to sTf. This is likely because citrate's role in metal transport has not been well characterized in humans ${ }^{11,21,22}$ although it has been more extensively studied in bacteria. ${ }^{23,24}$ In the context of $\mathrm{Fe}-$ sTf transport, citrate is unable to substitute for carbonate as a synergistic anion. ${ }^{12}$ Rather, at high concentrations, it can compete with sTf for binding of the metal. ${ }^{12,25}$ This is quite distinct from the synergistic anion role that citrate can play for the ferric binding protein $\mathrm{A}(\mathrm{FbpA})$, which has a metal binding site similar to that of sTf. $^{24}$

In this work, we investigate the molecular mechanism that the body uses to bind and transport Ti(IV) released in vivo by focusing on the interaction of citrate and sTf in this process. An $\mathrm{X}$-ray structure of a $\mathrm{Ti}(\mathrm{IV})$-bound sTf complex illuminates the unprecedented role of citrate as a synergistic anion for $\mathrm{Ti}(\mathrm{IV})$ coordination facilitating an open conformation. ${ }^{13} \mathrm{C}$ NMR spectroscopy and elemental and molecular quantitative studies further reveal the molecular details of the $\mathrm{Ti}(\mathrm{IV})$ coordination. Calorimetric and cytotoxicity studies inform on the stability of the $\mathrm{Ti}(\mathrm{IV})-$ sTf complex and its impact on the blood speciation, transport, and activity of the metal. In exploring the synergistic regulation of $\mathrm{Ti}(\mathrm{IV})$ by sTf and citrate, this work provides new insight into the improved design of $\mathrm{Ti}(\mathrm{IV})$ anticancer agents. More broadly, it also elucidates on the structural requirements for the sTf anion-dependent cellular uptake of nonferric metals in the body.

\section{RESULTS AND DISCUSSION}

Citrate Participates in Ti(IV) Transport by sTf. To understand the role that citrate plays in the leaching of Ti from Ti-containing implants, ${ }^{19,20}$ a model for the blood speciation ( $\mathrm{pH} 7.4$ ) of $\mathrm{Ti}(\mathrm{IV})$ citrate was proposed (Figure S1, Supporting Information). Blood is the first tissue that the implant contacts, and it constitutes a major component of the 
peri-implant space particularly because of the blood requirement for bone healing. ${ }^{26}$ This $\mathrm{Ti}(\mathrm{IV})$ citrate blood speciation was modeled using $\mathrm{Ti}(\mathrm{IV})$ citrate formation constants ${ }^{27}$ and the blood levels of citrate $(100 \mu \mathrm{M})^{28}$ and $\mathrm{Ti}(\mathrm{IV})$ (maximum) following release from implants $(0.28 \mu \mathrm{M}) .^{7}$ The results indicate that citrate helps the $\mathrm{Ti}$ to leach by forming very stable complexes with the metal, of which $89 \%$ of the speciation consists of the $\mathrm{Ti}(\mathrm{IV})$ tricitrate complex $\left(\left[\mathrm{Ti}(\text { citrate })_{3}\right]^{8-}\right)$. In this complex, the three citrates coordinate as bidentate ligands via the $\alpha$-hydroxyl and $\alpha$-carboxyl oxygens (Figure S1). The $\mathrm{Ti}(\mathrm{IV})$ tricitrate complex is expected to be short-lived in blood because of the lability of the complex and the strong affinity that sTf has for the metal. ${ }^{29}$ The complex has previously been shown to rapidly deliver $\mathrm{Ti}(\mathrm{IV})$ to physiological amounts of sTf (30-60 $\mu \mathrm{M})$ at its two metal binding sites, producing a ligand to metal charge transfer (LMCT) absorbance at $321 \mathrm{~nm}$ with an extinction coefficient of $\sim 10000 \mathrm{M}^{-1} \mathrm{~cm}^{-1}$ based on $\mathrm{Ti}$ (IV) concentration. $^{29,30}$ This delivery is nearly stoichiometric at citrate concentrations as high as $10 \mathrm{mM}^{29}$ Saturation of the $\mathrm{Ti}(\mathrm{IV})$ coordination sites by the three citrates appears to be a prerequisite for yielding this $\mathrm{Ti}(\mathrm{IV})_{2}-$ sTf complex because it prevents metal hydrolysis. ${ }^{27}$ This is true of low micromolar levels of the extremely aqueous unstable $\mathrm{Ti}(\mathrm{IV})$ source, titanocene dichloride, which would precipitate as $\mathrm{Ti}(\mathrm{IV})$ oxide species at $\mathrm{pH} 7.4^{31}$ but becomes converted to $\mathrm{Ti}(\mathrm{IV})$ citrate species in the presence of $100 \mu \mathrm{M}$ citrate. When sTf is also present in these solutions, the $\mathrm{Ti}(\mathrm{IV})_{2}-$ sTf complex forms with the expected characteristic spectroscopic signals.

Citrate Is a Synergistic Anion for sTf Binding of Ti(IV) and Facilitates an Open Conformation. The role of citrate as more than a delivery agent of $\mathrm{Ti}(\mathrm{IV})$ to sTf was examined by ${ }^{13} \mathrm{C}$ isotopic labeling of the citrate (Figure S1). ${ }^{32}$ The $\alpha$ carboxyl carbon was labeled $\left(\left(1^{\prime}-{ }^{13} \mathrm{C}\right)\right.$ citrate $)$ because it experiences a significant downfield shift of $\Delta \delta 8.6$ when the $\mathrm{Ti}(\mathrm{IV})$ coordinates. ${ }^{33} \mathrm{STf}$ was $\mathrm{Ti}(\mathrm{IV})$ saturated with an excess of $\left[\mathrm{Ti}\left(\left(1^{\prime}{ }^{-13} \mathrm{C}\right) \text { citrate }\right)_{3}\right]^{8-}$ in a $\mathrm{pH} 7.4$ buffer containing $2 \mathrm{mM}$ ${ }^{13} \mathrm{C}$-citrate and $5 \mathrm{mM}{ }^{13} \mathrm{C}$-bicarbonate. The ${ }^{13} \mathrm{C}$ NMR spectrum (Figure 2 ) of the dialyzed $\mathrm{Ti}(\mathrm{IV})$-bound protein $(\sim 1 \mathrm{mM})$ was compared with the spectra for $\left(1^{\prime}{ }^{13} \mathrm{C}\right)$ citrate and ${ }^{13} \mathrm{C}$ bicarbonate in the presence and absence of apo-sTf and

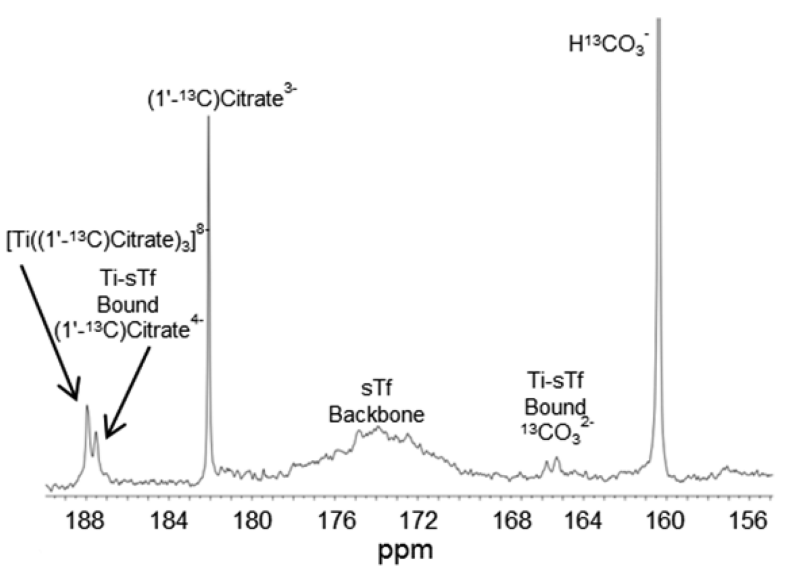

Figure 2. Citrate and carbonate serve as synergistic anions for sTf binding of $\mathrm{Ti}(\mathrm{IV})$. The proton-decoupled ${ }^{13} \mathrm{C}$ NMR spectra of $1 \mathrm{mM}$ transferrin in the presence of 2 equiv of $\mathrm{Ti}(\mathrm{IV})$ and ${ }^{13} \mathrm{C}$ isotopically labeled bicarbonate $(5 \mathrm{mM})$ and citrate $(2 \mathrm{mM})$. The 165.2 and 165.5 ppm signals are due to bound carbonate at the metal binding site, and the $187.5 \mathrm{ppm}$ signal is due to the bound citrate.
$\left[\mathrm{Ti}\left(\left(1^{\prime}{ }^{-13} \mathrm{C}\right) \text { citrate }\right)_{3}\right]^{8-}$ (Figure S2, Supporting Information). The chemical shifts for $\left(1^{\prime}{ }^{13} \mathrm{C}\right)$ citrate and ${ }^{13} \mathrm{C}$-bicarbonate were identical in the controls. Three ${ }^{13} \mathrm{C}$ chemical shifts appear in the $\mathrm{Ti}(\mathrm{IV})$-bound protein sample. These are the shift at $187.52 \mathrm{ppm}$ attributed to $\mathrm{Ti}(\mathrm{IV})$-coordinated citrate and at 165.23 and $165.50 \mathrm{ppm}$ attributed to coordinated carbonate $^{30,34,35}$ at the metal binding site. Complementary experiments were performed to quantify the stoichiometry of $\mathrm{Ti}(\mathrm{IV})$ and citrate bound to sTf. The binding stoichiometry was determined to be sTf:Ti:citrate 1:1.91 \pm 0.07:1.68 \pm 0.04, indicating that for every bound $\mathrm{Ti}(\mathrm{IV})$ there is one molecule of citrate. These results suggest an unprecedented synergistic anion role for citrate in the sTf metal binding. An extensive previous study on synergistic anions and binding of $\mathrm{Fe}$ (III) showed that citrate could not substitute for carbonate as a synergistic anion. ${ }^{12}$ Instead the ligand competes with sTf for Fe(III) coordination. ${ }^{12,25}$ In the $\mathrm{Ti}(\mathrm{IV})$ situation, citrate displays an entirely different behavior and, rather than substitute for carbonate, it serves as an additional synergistic anion for sTf binding of $\mathrm{Ti}(\mathrm{IV})$. In this model for $\mathrm{Ti}(\mathrm{IV})$ coordination to sTf $\left.\left(\mathrm{Ti}_{2}-\text { sTf- }\left(\mathrm{CO}_{3}\right)_{2} \text { (citrate }\right)_{2}\right)$, Ti(IV) binds to both tyrosines as indicated by the presence of the LMCT absorbance and, as revealed by the ${ }^{13} \mathrm{C}$ NMR data, to both carbonate and citrate (Figure 1C). The citrate prevents coordination of the Asp and His moieties and thus would facilitate a metal-bound open conformation. This unusual coordination can be rationalized because $\mathrm{Ti}(\mathrm{IV})$ is a strong Lewis acid and would more favorably bind to the stronger Lewis base citrate oxygens of the $\alpha$-alkoxyl and $\alpha$-carboxyl groups. That the $\mathrm{Fe}$ (III) coordination is distinct can also be rationalized on similar grounds because $\mathrm{Fe}$ (III) is a weaker Lewis acid relative to $\mathrm{Ti}(\mathrm{IV})$ and would have a higher stability coordinated to the His and Asp. ${ }^{16}$ To confirm the unusual model for $\mathrm{Ti}(\mathrm{IV})$ coordination to $\mathrm{sTf}$, crystallization studies were performed.

The crystal structure of $\mathrm{Ti}(\mathrm{IV})$-bound sTf was solved to a resolution of $2.68 \AA$ by the molecular replacement method using the human apotransferrin structure (Protein Data Bank (PDB) accession code 2HAU) as the search model (Table 1$)^{25}$ The protein crystallized with two molecules in an asymmetric unit (PDB 5DYH) having an open conformation similar to that of the apo-sTf structure (Figure $3 \mathrm{~A}$ ). Ti(IV) is present only at the C-lobe binding site (Figure S3, Supporting Information) coordinated in a mode identical to that of the proposed solution structure (Figure 1C), the carbonate and citrate both serving as bidentate synergistic anions as confirmed by an omit map (Figure S4, Supporting Information). The $100 \mathrm{mM}$ citrate concentration used for crystallization appears to be responsible for this partially $\mathrm{Ti}(\mathrm{IV})$-bound species. A similar metal displacement effect by high citrate levels in the crystallization process yielded the apo-sTf structures (PDB 2HAU and $2 \mathrm{HAV}$ ) from samples that were initially $\mathrm{Fe}(\mathrm{III})$ saturated. $^{25}$ Nine metal-free citrate molecules bind to the protein dimer (Figure S5, Supporting Information), a finding similar to the apo-sTf structures.

The $\mathrm{Ti}(\mathrm{IV})$-bound $\mathrm{C}$-site reveals that citrate serves two distinct functions (Figure 3B). The citrate behaves as a synergistic anion that facilitates a metal-bound open conformation. A semiopen conformation has been previously observed with nitrilotriacetate and sulfate (Figure 1B); ${ }^{18}$ however, these structures may not represent a physiological state but likely are a product of crystallization conditions. The $\mathrm{Bi}(\mathrm{III})-\mathrm{NTA}$ containing structure, for example, was obtained via 
Table 1. Data Collection and Refinement Statistics for Ti(IV) Human Serum Transferrin (Molecular Replacement) ${ }^{a}$

\begin{tabular}{|c|c|}
\hline \multicolumn{2}{|l|}{ Data Collection } \\
\hline space group & $P 2_{1} 2_{1} 2_{1}$ \\
\hline \multicolumn{2}{|l|}{ cell dimensions } \\
\hline$a, b, c(\AA)$ & $88.28,102.02,197.90$ \\
\hline$\alpha, \beta, \gamma(\operatorname{deg})$ & $90.00,90.00,90.00$ \\
\hline resolution $(\AA)$ & $49.39-2.68(2.78-2.68)^{b}$ \\
\hline$R_{\text {sym }}$ & $0.09(0.78)$ \\
\hline$I / \sigma I$ & $33.0(2.2)$ \\
\hline completeness (\%) & $96(84)$ \\
\hline redundancy & $2.0(2.0)$ \\
\hline \multicolumn{2}{|l|}{ Refinement } \\
\hline resolution $(\AA)$ & $49-2.68$ \\
\hline no. reflections & 93205 \\
\hline$R_{\text {work }} / R_{\text {free }}$ & $0.20 / 0.24$ \\
\hline \multicolumn{2}{|l|}{ no. atoms } \\
\hline protein & 10375 \\
\hline ligand & 153 \\
\hline water & 0 \\
\hline \multicolumn{2}{|l|}{ B-factors } \\
\hline protein & 97.95 \\
\hline ligand & 147.44 \\
\hline \multicolumn{2}{|l|}{ rms deviations } \\
\hline bond lengths $(\AA)$ & 0.003 \\
\hline bond angles (deg) & 0.670 \\
\hline
\end{tabular}

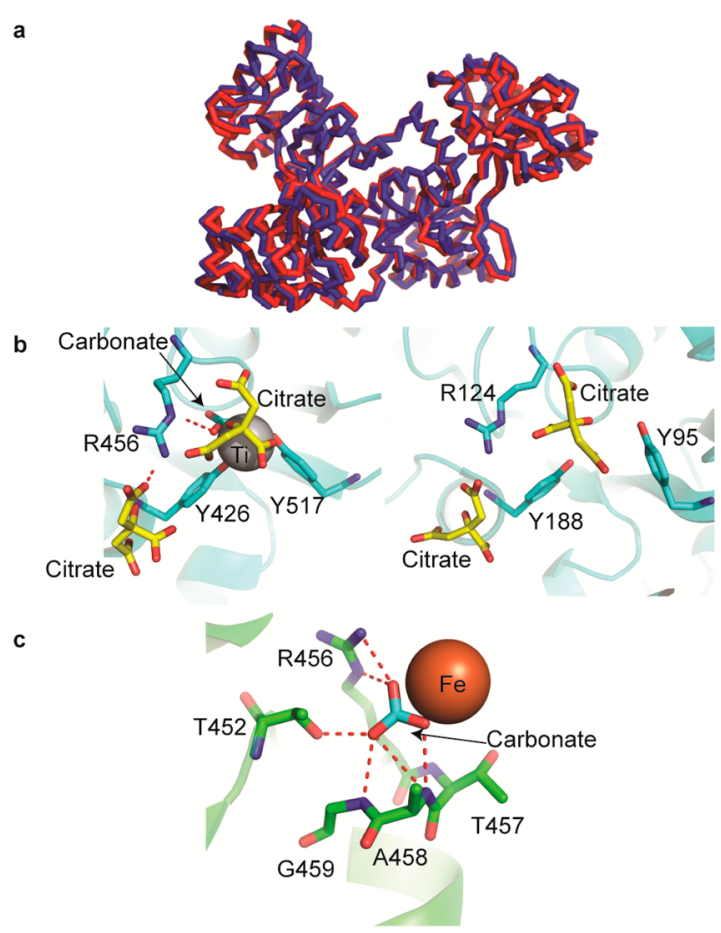

Figure 3. STf binds metals in both open and closed conformations mediated by anions. (a) Overlapping ribbon diagram of the apo-sTf (PDB code: $2 \mathrm{HAU}$, red) and Ti-sTf (blue) crystal structures. The two structures have a very similar conformation $(\mathrm{RSMD}=1.217)$. (b) $\mathrm{C}$ (left) and $\mathrm{N}$ (right) binding sites of the Ti-sTf protein crystals. (c) $\mathrm{CO}_{3}{ }^{2-}$ polar contacts as seen in the C-site of the sTf-Fe(III) bound form (3QYT). the use of the soaking-in method of a concentrated solution of $\mathrm{Bi}(\mathrm{NTA})$ applied to crystals of $\mathrm{Fe}_{2}-\mathrm{sTf}^{18}$ No insight into the possibility of metal uptake by an open conformation for metalbound sTf was offered in this work. However, the Ti(IV)bound open conformation exists at endogenous citrate levels and $\mathrm{pH}$ and suggests the physiological relevance of noncarbonate anions participating in sTf metal transport.

In the crystal structure of the $\mathrm{Ti}(\mathrm{IV})$-bound sTf, a second citrate (metal-free) binds near the metal binding site and operates as a nonsynergistic anion ${ }^{36,37}$ by inducing structural changes that weaken the metal affinity to the protein. This second citrate binds at high millimolar levels and forms a hydrogen bond with the carbonate-binding Arg residue (R456). This interaction partly inhibits R456 interaction with the carbonate and is likely why the carbonate and metal dissociate from the $\mathrm{N}$-site. In the $\mathrm{Fe}$ (III)-bound closed conformation structure, carbonate has multiple polar contacts with R456 in addition to other amino acids (Figure 3C). At the $\mathrm{N}$-site, one citrate is found directly in the metal binding site and another near the R456 but it does not engage in hydrogen bonding, an effect that may be due to reorganization following loss of the carbonate and metal ions. The Ti(IV)-bound sTf structure obtained is a transitory structure between a metal-bound and metal-free form. A physiologically relevant structure would be expected to have both $\mathrm{Ti}(\mathrm{IV})$ in an open conformation because $\mathrm{Ti}(\mathrm{IV})$ titration into both sites leads to comparable increase in the UV Vis LMCT absorbance.

The Open Conformation of Ti(IV)-Bound sTf Impacts Protein Stability and Cellular Metal Uptake and Release. The new model for $\mathrm{Ti}(\mathrm{IV})$ sTf coordination $\left(\mathrm{Ti}_{2}-\mathrm{sTf}-\right.$ $\left(\mathrm{CO}_{3}\right)_{2}$ (citrate $\left.)_{2}\right)$ requires a reconsideration of several aspects of its thermodynamics. STf binding of $\mathrm{Fe}$ (III) results in a major stabilization of the protein due to its closed conformation. The melting temperature $\left(T_{\mathrm{m}}\right)$ of the $\mathrm{C}$ - and $\mathrm{N}$-sites increase by 30 ${ }^{\circ} \mathrm{C}$ and $19{ }^{\circ} \mathrm{C}$, respectively, as monitored by differential scanning calorimetry (DSC). ${ }^{15}$ Binding of $\mathrm{Ti}(\mathrm{IV})$ in an open conformation should produce lesser stabilization, and DSC was used to measure this effect (Figure S6, Supporting Information). The addition of 1 equiv of $\mathrm{Ti}(\mathrm{IV})$ exhibits a preferential binding of $\mathrm{Ti}(\mathrm{IV})$ to the $\mathrm{C}$-site, similar to $\mathrm{Fe}(\mathrm{III})$, and an increase of its $T_{\mathrm{m}}$ by $18.5{ }^{\circ} \mathrm{C}$. At saturation of the protein, the $T_{\mathrm{m}}$ of the $\mathrm{N}$-site increases by $5{ }^{\circ} \mathrm{C}$ and the thermogram resembles a one-transition profile. While the $\mathrm{Ti}_{2}-$ sTf complex is less thermostable than $\mathrm{Fe}_{2}-\mathrm{sTf}$, the binding of $\mathrm{Ti}(\mathrm{IV})$ does significantly stabilize sTf on account of locking the $\mathrm{N} 2$ and $\mathrm{C} 2$ subdomains into a fixed position due to coordination to the two tyrosines. In the $\mathrm{Fe}(\mathrm{III})$ version of the protein (PDB code 2HAU), metal binding to these two subdomains contributes most to sTf stabilization. 25

The original determination of the $\mathrm{Ti}(\mathrm{IV})$ affinity to $\mathrm{sTf}^{29}$ rested on the assumption that $\mathrm{Ti}(\mathrm{IV})$ coordinates exactly like $\mathrm{Fe}(\mathrm{III})$ does. Our crystal structure, like the DSC data, suggests that $\mathrm{Ti}(\mathrm{IV})$ has a higher affinity for the $\mathrm{C}$-site than it does for the $\mathrm{N}$-site. In vivo studies with the blood of people with $\mathrm{Ti}$ implants have shown that $\mathrm{Ti}(\mathrm{IV})$ appears exclusively bound to the $\mathrm{N}$-site. ${ }^{38}$ In the absence of conclusive $\mathrm{Ti}(\mathrm{IV})$ preferential site studies, the affinity constants were recalculated as site nonspecific constants using the previous data ${ }^{29}$ (Table S1, Supporting Information). The affinity constants at $\mathrm{pH} 7.4, \log$ $K_{\text {Site } 1}=35.8$ and $\log K_{\text {Site } 2}=34.7$, are extremely high. Even in the presence of $100 \mathrm{mM}$ citrate, $45 \mu \mathrm{M}$ sTf remains approximately $60 \% \mathrm{Ti}(\mathrm{IV})$ saturated. 
Comparing the relative affinities of $\mathrm{Ti}(\mathrm{IV})$ and $\mathrm{Fe}(\mathrm{III})$ to sTf is difficult because of their different coordination modes; nonetheless, some key differences in their interaction with sTf are important in the context of their delivery into cells. Transferrin uses an endocytotic process for intracellular delivery of metals through interaction with its receptor (TfR). The iron-binding structural reorganization of sTf is believed to be important for sTf recognition by the TfR at the cell membrane to initiate endocytosis. ${ }^{39}$ However, a recent mass spectrometric experiment reveals that the apoprotein is very capable of forming a stable complex with the TfR at neutral $\mathrm{pH}$ and indicates that a metal-induced structural reorganization is not a requirement. ${ }^{40}$ Some have argued that only a closed conformation of both lobes will facilitate metal-bound sTf to transport the metal into cells. This was the argument proposed for the physiological uptake of plutonium(IV) via the sTf route. ${ }^{10}$ The authors argue that the only way $\mathrm{Pu}(\mathrm{IV})$ can enter into cells is by being bound in a particular mixed-metal formulation where $\mathrm{Pu}(\mathrm{IV})$ is present at the $\mathrm{C}$-site and $\mathrm{Fe}(\mathrm{III})$ is present at the $\mathrm{N}$-site because in this formulation both metals are in a closed conformation. Interestingly, the authors never take into consideration the role of synergistic anions in the composition of $\mathrm{Pu}(\mathrm{IV})$-bound sTf. The lack of this information makes it difficult to elucidate the physical reality of the closedconformation requirement. However, $\mathrm{Ti}_{2}-\mathrm{sTf}$, despite its open conformation, has been shown to have a high affinity to the two protein binding sites of TfR1 $\left(K_{\mathrm{D} 1}=6.3 \mathrm{nM}\right.$ and $K_{\mathrm{D} 2}=410$ $\mathrm{nM}) .{ }^{41} \mathrm{~A}$ Ti(IV) uptake experiment was performed on A549 cells, known to overexpress $\mathrm{TfR} 1$, to determine if $\mathrm{Ti}_{2}-\mathrm{sTf}$ could deliver the metal into cells. An uptake of $3.3 \pm 0.6$ femtogram $\mathrm{Ti}$ /cell was determined in the soluble fraction of cell lysates, which was found to be statistically significant versus apo-sTf, $\mathrm{Fe}_{2}-$ sTf, and media only controls (Figure 4a). This finding complements a positron emission tomography study performed on EMT-6 tumor-bearing $\mathrm{BALB} / \mathrm{c}$ mice that showed ${ }^{45} \mathrm{Ti}(\mathrm{IV})-$ sTf uptake into the tumor cells following Ti-citrate administration. ${ }^{42}$ These results demonstrate that $\mathrm{TfR}$ is able to recognize an open-conformation of metal-bound sTf.

One aspect of $\mathrm{Ti}(\mathrm{IV})$ delivery into cells that is not well understood is its release from the endosome. Within the endosome, the $\mathrm{pH}$ decreases to 5.5 and metal affinity to sTf can dramatically change. At this $\mathrm{pH}, 100 \mu \mathrm{M}$ citrate has been reported to deplete sTf entirely of $\mathrm{Fe}(\mathrm{III}){ }^{43}$ This finding was confirmed in a side by side dialysis of $\mathrm{Fe}_{2}-$ sTf and $\mathrm{Ti}_{2}-\mathrm{sTf}$ against pH 5.5 buffered solutions containing $100 \mu \mathrm{M}$ citrate. The $\mathrm{Fe}(\mathrm{III})$ was completely removed, but the $\mathrm{Ti}(\mathrm{IV})$ remained entirely bound. In the case of $\mathrm{Fe}(\mathrm{III})$, the appropriate priming by the receptor is required so that chelation of $\mathrm{Fe}$ (III) and/or reduction of the metal to $\mathrm{Fe}$ (II) results in iron release from sTf and ultimate transport out of the endosome and into the cytosol for trafficking and storage. ${ }^{36,44}$ The reduction of Ti(IV) as a release mechanism from sTf within the endosome is not feasible. ${ }^{45}$ The higher affinity to sTf that $\mathrm{Ti}(\mathrm{IV})$ possesses versus $\mathrm{Fe}(\mathrm{III})$ at $\mathrm{pH} 5.5$ suggests that a powerful chelator will have to remove $\mathrm{Ti}(\mathrm{IV})$. Sadler et al. proposed that such a ligand could be $\mathrm{ATP}^{34}$ although no in vivo studies have been performed to confirm a chelation release mechanism.

Citrate and sTf Work in Synergism To Regulate Ti(IV) Cytotoxicity. A more prevalent pool of Ti(IV)-bound sTf in people with $\mathrm{Ti}$ implants suggests a greater uptake of $\mathrm{Ti}(\mathrm{IV})$ into cells. A study was conducted that determined the $\mathrm{Ti}$ (IV) released from implants must reach concentrations greater than a

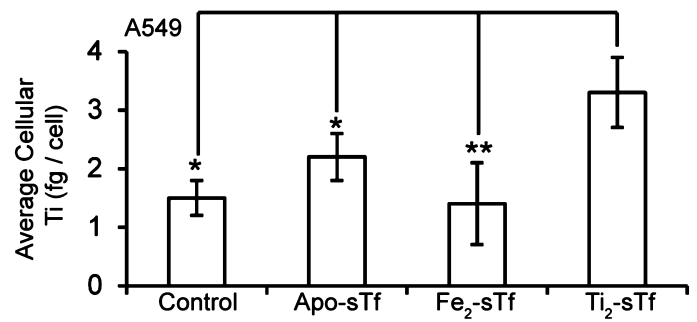

b
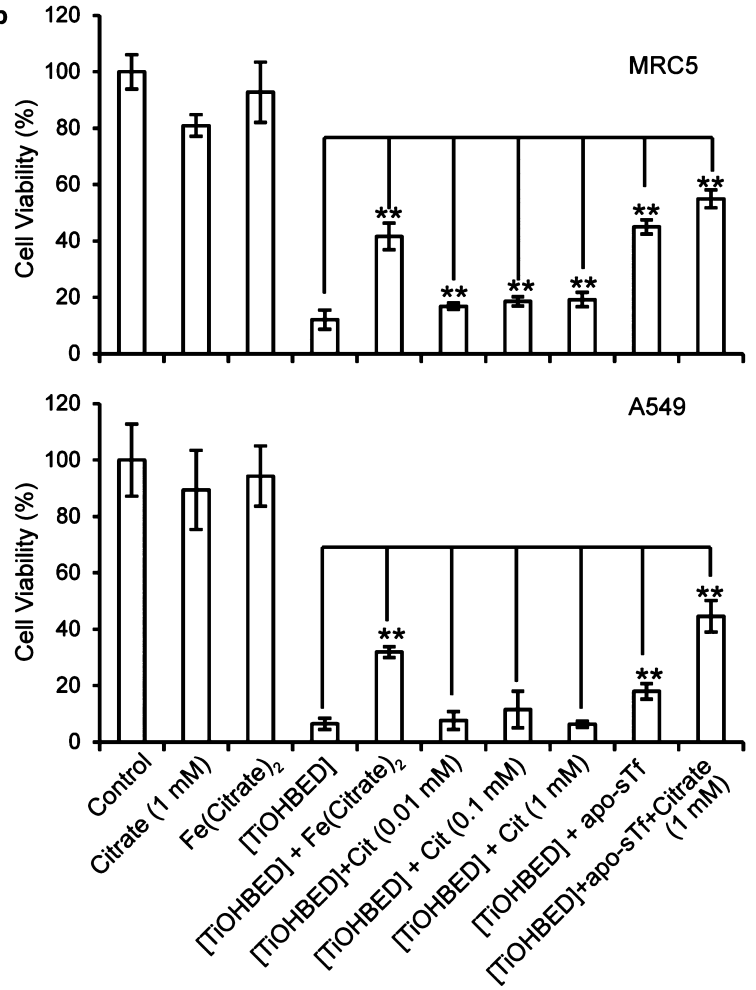

Figure 4. Transferrin delivers $\mathrm{Ti}(\mathrm{IV})$ into cells and controls its cytotoxicity with the aid of citrate. (a) A549 cells exhibit an elevated $\mathrm{Ti}(\mathrm{IV})$ content when treated with $\mathrm{Ti}_{2}-\mathrm{sTf}$ versus treatment with aposTf, $\mathrm{Fe}_{2}-\mathrm{sTf}$, and media alone (control) $(N=5)$. (b) The viability of the cell lines A549 and MRC when treated with [TiOHBED]- $(0.1$ $\mathrm{mM}$ ) alone versus with [TiOHBED $]^{-}$and citrate $(0.01-1 \mathrm{mM})$, aposTf $(0.03 \mathrm{mM})$, or citrate $(1 \mathrm{mM})$ and apo-sTf $(0.03 \mathrm{mM})$ combined. The results demonstrate that the combination of apo-sTf and citrate attenuate the cytotoxicity of $[\mathrm{TiOHBED}]^{-}$. $\left[\mathrm{Fe}(\right.$ citrate $\left.){ }_{2}{ }^{5-}\right]=0.1 \mathrm{mM}$. Student's $t$ test, $* *, p$-value $<0.01, *, p$-value $<0.05$.

$100 \mu \mathrm{M}$ to exhibit any significant cytotoxicity, ${ }^{46}$ an amount that largely exceeds the actual levels released. More importantly, $\mathrm{Ti}_{2}-$ sTf- $\left(\mathrm{CO}_{3}\right)_{2}$ (citrate $)_{2}$ exhibits no cytotoxicity even at 100 $\mu \mathrm{M}^{47}$ STf may be responsible for maintaining nontoxic Ti(IV) speciation in blood, with citrate critical to this speciation. This finding has important implications on the design of $\mathrm{Ti}(\mathrm{IV})$ anticancer therapeutics.

The two lead $\mathrm{Ti}$ (IV) compounds (titanocene dichloride and budotitane) that advanced to clinical trials demonstrated poor efficacy in patients presumably because of their hydrolytic instability. Nonetheless, much effort has been devoted to the development of different families of $\mathrm{Ti}(\mathrm{IV})$ compounds as anticancer agents. For these newer compounds the identity of the ligands is crucial to their activities. ${ }^{48-50}$ An anticancer $\mathrm{Ti}(\mathrm{IV})$ complex was synthesized with the chelator $N, N^{\prime}$-bis $(o$ hydroxybenzyl)ethylenediamine- $N, N^{\prime}$-diacetic acid (HBED), to exploit its high affinity for $\mathrm{Fe}(\mathrm{III}) .^{50}$ The $[\mathrm{TiO}(\mathrm{HBED})]^{-}$ complex is cytotoxic against A549 (cancerous) and MRC5 


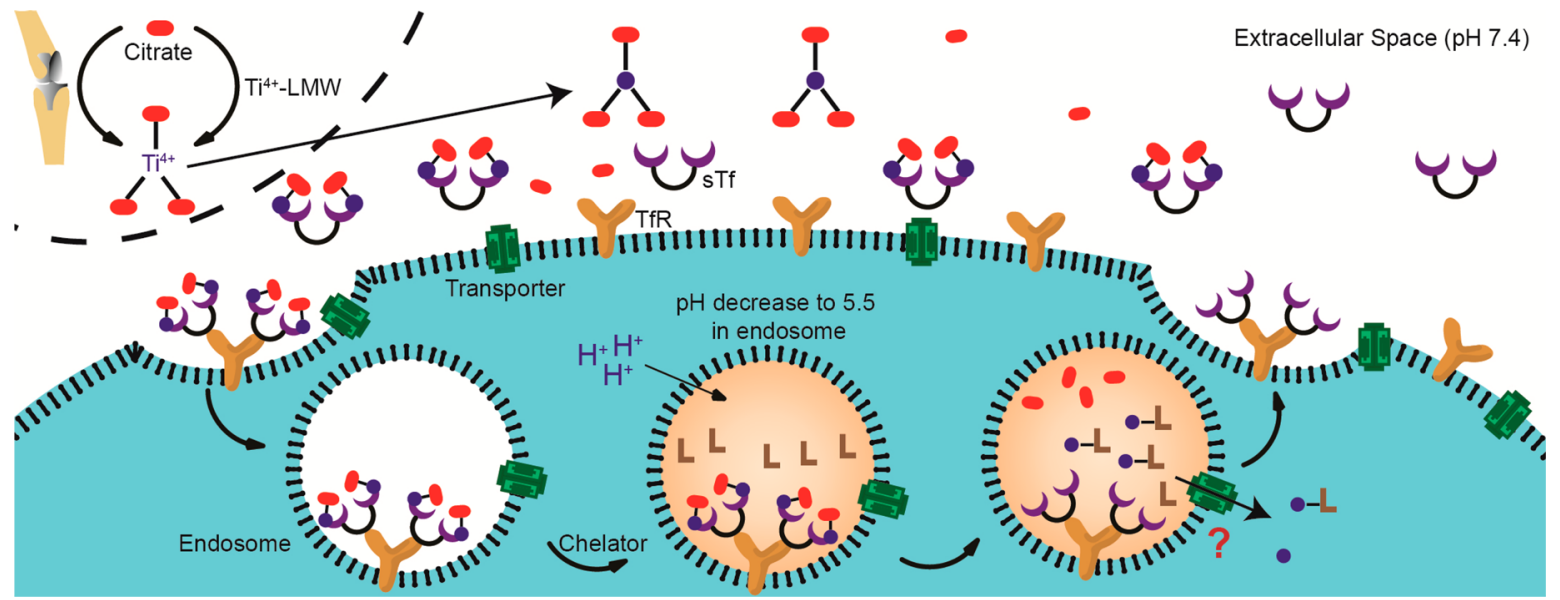

Figure 5. Proposed mechanism of sTf-mediated cellular delivery of Ti from Ti-implants and its LMW compounds as regulated by citrate. Citrate binds $\mathrm{Ti}(\mathrm{IV})$ released from implants or from LMW compounds that enter the bloodstream and then delivers the Ti(IV) to sTf. Ti(IV)-bound sTf is recognized by the transferrin receptor (TfR), which transports the metal into the cell via endocytosis. Ti(IV) saturation of sTf may not be a requirement. A chelator ( $\mathrm{L}$, unknown) then removes $\mathrm{Ti}(\mathrm{IV})$ from the protein complex, and the metal is released into the cytoplasm by a transporter (unknown).

(noncancerous) human lung cells and is believed to operate by releasing $\mathrm{Ti}(\mathrm{IV})$ into cells due to its higher affinity for $\mathrm{Fe}(\mathrm{III})$, thus depleting the cells of $\mathrm{Fe}(\mathrm{III})$ and facilitating $\mathrm{Ti}(\mathrm{IV})$ to reach its intracellular target(s). The complex is quite stable in solution and has been shown to be unable to deliver Ti(IV) directly to sTf; however, this study was conducted in the absence of citrate. ${ }^{47}$ A citrate concentration dependence study was performed in the reaction between $90 \mu \mathrm{M}$ [TiO(HBED) $]^{-}$ and $45 \mu \mathrm{M}$ sTf. No metal exchange occurred in the absence of citrate, but $26 \pm 1.7 \% \mathrm{Ti}(\mathrm{IV})$ saturation occurred at $100 \mu \mathrm{M}$ citrate and $71 \pm 11 \%$ saturation occurred at $10 \mathrm{mM}$ concentration. These results suggest that physiologic citrate can effectively compete with micromolar levels of HBED for binding of $\mathrm{Ti}(\mathrm{IV})$ to facilitate delivery to sTf.

The impact of this competition on the cytotoxicity of $[\mathrm{TiO}(\mathrm{HBED})]^{-}$against A549 and MRC5 cells was examined. MTT assays were performed in DMEM media supplemented with $10 \%$ fetal bovine serum. FBS contains 22.5 to $27.5 \mu \mathrm{M}$ sTf and is $55 \%$ to $92 \% \mathrm{Fe}(\mathrm{III})$ saturated. ${ }^{51} \mathrm{~A}$ citric acid assay measured $509 \pm 76 \mu \mathrm{M}$ citrate in FBS. This amounts to significant levels of citrate and Fe(III)-bound sTf supplied by FBS in the MTT assay. Supplementation of citrate up to $1 \mathrm{mM}$ into the media slightly improved the viability of MRC5 cells treated with $100 \mu \mathrm{M}[\mathrm{TiO}(\mathrm{HBED})]^{-}$but had no effect on the A549 cells (Figure 4b). Addition of $30 \mu \mathrm{M}$ apo-sTf substantially improved the viability of both cells. For the MRC5 cells, the improvement was even greater than the addition of $100 \mu \mathrm{M}$ $\mathrm{Fe}$ (citrate) ${ }_{2}{ }^{5-}$, which is proposed to counter the depletion of intracellular $\mathrm{Fe}$ (III) by HBED. ${ }^{50}$ The combination of $30 \mu \mathrm{M}$ sTf and $1 \mathrm{mM}$ citrate had the greatest impact on improving the viabilities of both cell lines from $6 \%$ to $12 \%$ to nearly $50 \%$ viable. The effect of supplemented citrate alone is probably low because the cell lines might employ the FBS-provided sTf to take advantage of $\mathrm{Fe}$ (III) bound to it. When citrate and apo-sTf are supplemented together, the two work together to dissociate $[\mathrm{TiO}(\mathrm{HBED})]^{-}$and capture the $\mathrm{Ti}(\mathrm{IV})$. This finding sheds new light as to why the two lead Ti(IV) compounds may have failed in clinical trials. Valentine et al. previously suggested that the formulation for administering titanocene dichloride into patients transforms the compound into a different $\mathrm{Ti}(\mathrm{IV})$ complex with decreased cytotoxicity. ${ }^{52}$ While the suggestion is plausible, it is more likely that following administration of these compounds into patients, they quickly dissociated, converting into the $\mathrm{Ti}_{2}-\mathrm{sTf}-\left(\mathrm{CO}_{3}\right)_{2}$ (citrate $)_{2}$ complex, which we have previously demonstrated to not show any cytotoxicity at micromolar concentrations. ${ }^{47}$ Our own work demonstrating the rapid sTf binding of $\mathrm{Ti}(\mathrm{IV})$ from titanocene dichloride in the presence of physiological levels of citrate and carbonate supports this theory. Future efforts in the design of $\mathrm{Ti}(\mathrm{IV})$ anticancer agents must take into consideration the citrate and sTf content in the cell media when assessing the cytotoxicity of these agents.

\section{CONCLUSIONS}

In summary, while $\mathrm{Ti}$ leaching from implants is a concern in terms of the material stability in a biological environment, surprisingly the actual released $\mathrm{Ti}(\mathrm{IV})$ pool does not concentrate to toxic levels. Our structural, binding, thermal denaturation, and cellular studies suggest that citrate controls the toxicity of $\mathrm{Ti}(\mathrm{IV})$ upon release by transporting it to sTf, remaining bound as a synergistic anion in an open protein conformation, and providing a highly stabilizing coordination for the metal. This interaction may be part of a molecular mechanism already in effect in vivo for all sources of soluble $\mathrm{Ti}(\mathrm{IV})$ in people, in which citrate and sTf work in synergism to transform $\mathrm{Ti}(\mathrm{IV})$ into a nontoxic form that is able to use the $\mathrm{Fe}$ (III) transport pathway to enter into cells without inhibiting intracellular iron-dependent pathways (Figure 5). This work demonstrates the importance of evaluating the influence of physiological anions on transferrin trafficking of nonferric metal ions and also highlights the need to evaluate their contribution for the effective design of nonferric metal therapeutics.

\section{ASSOCIATED CONTENT}

\section{Supporting Information}

The Supporting Information is available free of charge on the ACS Publications website at DOI: 10.1021/jacs.6b01966.

Detailed experimental section, supplementary figures, and table (PDF)

CIF data (CIF) 


\section{AUTHOR INFORMATION}

\section{Corresponding Author}

*atinoc09278@gmail.com

\section{Author Contributions}

${ }^{\#}$ These authors contributed equally.

Notes

The authors declare no competing financial interest.

\section{ACKNOWLEDGMENTS}

We thank Prof. Alan Saghatelian, Yahaira M. Cruz, and Aleannette López for their valuable input to this manuscript. A.D.T., S.S., Y.D., and S.A.L-R. are supported by NIH SC1 (5SC1CA190504-02) provided by the NIGMS and NCI. A.D.T. is also supported by funding from the Puerto Rico Science, Technology, and Research Trust (agreement no. 2013000019), the University of Puerto Rico Score Stabilization Grant, and the Department of Chemistry at UPR RP. N.N. is supported by the Department of Biological Sciences at Purdue University and by the National Institute of Allergy and Infectious Diseases (1K22AI113078-01). M.S. is supported by an NSF IFN graduate fellowship (EPS-01002410). We thank the staff at the Advanced Photon Source at Argonne National Laboratory (ID22 SER-CAT beamline).

\section{REFERENCES}

(1) Knauss, K. G.; Dibley, M. J.; Bourcier, W. L.; Shaw, H. F. Appl. Geochem. 2001, 16, 1115.

(2) Shi, H. B.; Magaye, R.; Castranova, V.; Zhao, J. S. Part. Fibre Toxicol. 2013, 10, 15.

(3) Buettner, K. M.; Valentine, A. M. Chem. Rev. 2012, 112, 1863.

(4) Sansone, V.; Pagani, D.; Melato, M. Clin. Cases Miner. Bone Metab. 2013, 10, 34.

(5) Oshida, Y. Biomaterials Science: An Introduction to Materials in Medicine, 3rd ed.; Elsevier Inc.: New York, 2013.

(6) Barry, N. P. E.; Sadler, P. J. Chem. Commun. 2013, 49, 5106.

(7) Nuevo-Ordonez, Y.; Montes-Bayon, M.; Blanco-Gonzalez, E.; Paz-Aparicio, J.; Raimundez, J. D.; Tejerina, J. M.; Pena, M. A.; SanzMedel, A. Anal. Bioanal. Chem. 2011, 401, 2747.

(8) Williams, J.; Moreton, K. Biochem. J. 1980, 185, 483.

(9) Vincent, J. B.; Love, S. Biochim. Biophys. Acta, Gen. Subj. 2012, 1820, 362 .

(10) Jensen, M. P.; Gorman-Lewis, D.; Aryal, B.; Paunesku, T.; Vogt, S.; Rickert, P. G.; Seifert, S.; Lai, B.; Woloschak, G. E.; Soderholm, L. Nat. Chem. Biol. 2011, 7, 560.

(11) Crossgrove, J. S.; Allen, D. D.; Bukaveckas, B. L.; Rhineheimer, S. S.; Yokel, R. A. NeuroToxicology 2003, 24, 3.

(12) Schlabach, M. R.; Bates, G. W. J. Biol. Chem. 1975, 250, 2182.

(13) Bates, G. W.; Schlabach, M. R. J. Biol. Chem. 1975, 250, 2177.

(14) Noinaj, N.; Easley, N. C.; Oke, M.; Mizuno, N.; Gumbart, J.; Boura, E.; Steere, A. N.; Zak, O.; Aisen, P.; Tajkhorshid, E.; Evans, R. W.; Gorringe, A. R.; Mason, A. B.; Steven, A. C.; Buchanan, S. K. Nature 2012, 483, 53.

(15) Lin, L. N.; Mason, A. B.; Woodworth, R. C.; Brandts, J. F. Biochemistry 1994, 33, 1881.

(16) Li, H. Y.; Sadler, P. J.; Sun, H. Z. Eur. J. Biochem. 1996, 242, 387.

(17) Harris, W. R.; Carrano, C. J. J. Inorg. Biochem. 1984, 22, 201.

(18) Yang, N.; Zhang, H. M.; Wang, M. J.; Hao, Q.; Sun, H. Z. Sci. Rep. 2012, 2, 999.

(19) Bruneel, N.; Helsen, J. A. J. Biomed. Mater. Res. 1988, 22, 203.

(20) Silwood, C. J. L.; Grootveld, M. Biochem. Biophys. Res. Commun. 2005, 330, 784.

(21) Sturrock, A.; Alexander, J.; Lamb, J.; Craven, C. M.; Kaplan, J. J. Biol. Chem. 1990, 265, 3139.

(22) Kaplan, J.; Jordan, I.; Sturrock, A. J. Biol. Chem. 1991, 266, 2997.

(23) Lensbouer, J. J.; Doyle, R. P. Crit. Rev. Biochem. Mol. Biol. 2010, $45,453$.
(24) Weaver, K. D.; Gabricevic, M.; Anderson, D. S.; Adhikari, P.; Mietzner, T. A.; Crumbliss, A. L. Biochemistry 2010, 49, 6021.

(25) Wally, J.; Halbrooks, P. J.; Vonrhein, C.; Rould, M. A.; Everse, S. J.; Mason, A. B.; Buchanan, S. K. J. Biol. Chem. 2006, 281, 24934.

(26) Kuzyk, P. R. T.; Schemitsch, E. H. Indian J. Orthop. 2011, 45, 108 .

(27) Collins, J. M.; Uppal, R.; Incarvito, C. D.; Valentine, A. M. Inorg. Chem. 2005, 44, 3431.

(28) Tomisek, A. J.; Winkler, E. M.; Natelson, S. Clin. Chem. 1975, 21, 730 .

(29) Tinoco, A. D.; Valentine, A. M. J. Am. Chem. Soc. 2005, 127, 11218.

(30) Tinoco, A. D.; Incarvito, C. D.; Valentine, A. M. J. Am. Chem. Soc. 2007, 129, 3444.

(31) Toney, J. H.; Marks, T. J. J. Am. Chem. Soc. 1985, 107, 947.

(32) Winkel, C.; Buitenhuis, E. G.; Lugtenburg, J. Recl. Trav. Chim. Pays-Bas-J. R. Neth. Chem. Soc. 1989, 108, 51.

(33) Deng, Y. F.; Zhou, Z. H.; Wan, H. L. Inorg. Chem. 2004, 43, 6266.

(34) Guo, M. L.; Sun, H. Z.; McArdle, H. J.; Gambling, L.; Sadler, P. J. Biochemistry 2000, 39, 10023.

(35) Messori, L.; Orioli, P.; Banholzer, V.; Pais, I.; Zatta, P. FEBS Lett. 1999, 442, 157.

(36) Steere, A. N.; Byrne, S. L.; Chasteen, N. D.; Mason, A. B. Biochim. Biophys. Acta, Gen. Subj. 2012, 1820, 326.

(37) Marques, H. M.; Watson, D. L.; Egan, T. J. Inorg. Chem. 1991, 30, 3758.

(38) Nuevo-Ordonez, Y.; Montes-Bayon, M.; Gonzalez, E. B.; SanzMedel, A. Metallomics 2011, 3, 1297.

(39) Cheng, Y.; Zak, O.; Aisen, P.; Harrison, S. C.; Walz, T. Cell 2004, 116, 565 .

(40) Leverence, R.; Mason, A. B.; Kaltashov, I. A. Proc. Natl. Acad. Sci. U. S. A. 2010, 107, 8123.

(41) Tinoco, A. D.; Eames, E. V.; Valentine, A. M. J. Am. Chem. Soc. 2008, 130, 2262.

(42) Vavere, A. L.; Welch, M. J. J. Nucl. Med. 2005, 46, 683.

(43) Gumerov, D. R; Kaltashov, I. A. Anal. Chem. 2001, 73, 2565.

(44) Dhungana, S.; Taboy, C. H.; Zak, O.; Larvie, M.; Crumbliss, A. L.; Aisen, P. Biochemistry 2004, 43, 205.

(45) Parker Siburt, C. J.; Lin, E. M.; Brandt, S. J.; Tinoco, A. D.; Valentine, A. M.; Crumbliss, A. L. J. Inorg. Biochem. 2010, 104, 1006. (46) Soto-Alvaredo, J.; Blanco, E.; Bettmer, J.; Hevia, D.; Sainz, R. M.; Lopez Chaves, C.; Sanchez, C.; Llopis, J.; Sanz-Medel, A.; MontesBayon, M. Metallomics 2014, 6, 1702.

(47) Tinoco, A. D.; Thomas, H. R.; Incarvito, C. D.; Saghatelian, A.; Valentine, A. M. Proc. Natl. Acad. Sci. U. S. A. 2012, 109, 5016.

(48) Schur, J.; Manna, C. M.; Deally, A.; Koster, R. W.; Tacke, M.; Tshuva, E. Y.; Ott, I. Chem. Commun. 2013, 49, 4785.

(49) Immel, T. A.; Grutzke, M.; Spate, A. K.; Groth, U.; Ohlschlager, P.; Huhn, T. Chem. Commun. 2012, 48, 5790.

(50) Parks, T. B.; Cruz, Y. M.; Tinoco, A. D. Inorg. Chem. 2014, 53, 1743.

(51) Kakuta, K.; Orino, K.; Yamamoto, S.; Watanabe, K. Comp. Biochem. Physiol. A-Physiol. 1997, 118, 165.

(52) Buettner, K. M.; Snoeberger, R. C., III; Batista, V. S.; Valentine, A. M. Dalton Trans. 2011, 40, 9580. 